\title{
MYCOLOGICAL EVALUATION OF SALTED HYDROCYNUS FORSKALII FISH IN ASSIUT GOVERNORATE
}

\author{
H.A. ISMAIL ${ }^{* @}$; M.A. ISMAIL ${ }^{* *}$; H.Y. AHMED ${ }^{*}$ and A.K. YOUSSEF \\ ${ }^{*}$ Food Hygiene Department, Faculty of Veterinary Medicine, Assiut University, Egypt \\ ** Botany Department, Faculty of Science, Assiut University, Egypt \\ Mobile: $+20-01019757109$, Fax: $+20-882366503$
}

\section{ABSTRACT}

Received at: 29/6/2015

Accepted: 30/7/2015
The present study was performed to evaluate the mycological quality of 25 samples of commercially available salted fish (Hydrocynus forskalii) sold in retails outlets in Assiut Governorate, Egypt. Three isolation media [Dicloran Rose Bengal Chloramphenicol (DRBC); $10 \% \mathrm{NaCl}$ malt extract agar and $20 \% \mathrm{NaCl}$ malt extract agar] were used for counting and identification of fungi. Also, sensory quality, $\mathrm{pH}$ values and sodium chloride percentage were assessed. Sensory evaluation revealed that $12 \%$ of the samples were unacceptable while the remaining $88 \%$ samples were acceptable. Mean $\mathrm{pH}$ values were $7.04 \pm 0.27$ and $6.81 \pm 0.35$ for skin and muscular parts, respectively. Sodium chloride percentage ranged from 10.23 to $17.55 \%$ with a mean value of $15.03 \pm 1.77$. A total of 75 species in addition to some unidentified species of yeasts, dematiaceous hyphomycetes and pure mycelia were isolated from all samples on DRBC (61 species), $10 \% \mathrm{NaCl}$ malt extract agar (46) and $20 \% \mathrm{NaCl}$ malt extract agar (19). Aspergillus, Petromyces, Penicillium, Eurotium, Cladosporium and yeasts were the most common fungi recovered on the three media. Some of the isolated fungi are toxigenic and have the ability to produce mycotoxins which have potential hazards on human health.

Key words: Fungi, Sensory, pH, Sodium chloride, Salted Fish

\section{INTRODUCTION}

Fish and fish products have traditionally been a popular part of the diet in many parts of the world, and in tropical areas including Africa and Far East where it constitutes a major part of the diet (FAO, 1981a and FAO, 1994). In poorest societies, fish, particularly as cured products, is often a significant source of high quality dietary protein, as well as being the least expensive source of animal protein available (Perisse et al., 1974; Balachandran et al., 1978; FAO, 1981a).

Fish constitute a part of protein in the diet of some people in Egypt. Salting is the most widespread and cheapest method for fish preservation, but the water activity of the salted fish is often not low enough to prevent mould spoilage. Fungi associated with salting fish differ according to the condition under which fish is stored (Ismail et al., 1994). The salt curing may be done by unscientific methods under unhygienic conditions. As a result, the products are grossly contaminated with dirt, sand, microbes and insect infestation and have only limited shelf life (Govindan, 1985).

Fungal contamination of fish is considered the main cause of spoilage which leads to off flavour and unpalatable taste and may constitute a public health hazard as well as severe economic losses (Karnop, 1980; Dorner, 1983; Ward and Baaj, 1988; Dimond and Kendall, 2011). Many strains of moulds isolated from different types of fish are able to produce toxic metabolites (mycotoxins) which have potential hazards on human health as they have carcinogenic effect. High mycotoxins levels could lead to liver cancer, whereas subacute levels are responsible for liver disease and organ damage (Pitt, 2000).

Since salted fish constitute an important part of the diet of great portion of consumers in Egypt and since it is subjected to many risks of contamination from various sources, therefore this study was performed to evaluate the mycological status of commercially available salted fish as well as estimation of $\mathrm{pH}$ value and $\mathrm{NaCl} \%$. 


\section{MATERIALS and METHODS}

\section{Collection of samples}

Twenty five samples of salted fish (Hydrocynus forskalii Cuvier, 1819) were collected randomly from retail markets of different sanitation levels at Assiut city, Egypt, during the period from June 2010 to April 2011. The samples were transferred to the laboratory under aseptic condition without undue delay to be examined for their quality and fungal content.

\section{Preparation of samples (AOAC, 1995)}

The fish heads, scales, tails, fins, guts and bones were removed and discarded. The fish were filleted to obtain all flesh and skin from head to tail and from top of back to belly on both sides. Some pieces of the fillet were selected randomly and kept separately at $4^{\circ} \mathrm{C}$ for sensory assessment. The other parts of the fillet were thoroughly homogenized in a sterile mortar and used for mycological and chemical analyses.

\section{Sensory evaluation (Ikeme, 1986)}

Subjective evaluation of the salted fish quality was carried out by three taste panels from the Food Hygiene Department, Faculty of Veterinary Medicine, Assiut University, Egypt. Quality attributes studied included appearance, juiciness, saltiness, rancidity, flavor and general acceptability. Panel members scored all factors on a 5-point hedonic scale according to Ikeme (1986).

\section{Determination of $\mathbf{p H}$}

The $\mathrm{pH}$ value was measured using $\mathrm{pH}$-meter instrument (Jenway 3505, UK) according to Lyhs et al. (1998).
Estimation of sodium chloride percentage Percentage of $\mathrm{NaCl}$ content was measured according to AOAC (1980).

\section{Mycological examination}

Fish samples were prepared according to the technique recommended by American Public Health Association (1985). To 10 grams of muscle or skin sample, $90 \mathrm{ml}$ of sterile saline solution $(0.85 \% \mathrm{w} / \mathrm{v})$ were added aseptically and thoroughly mixed for not more than 2.5 minutes using a sterile waring blender or homogenizer, to avoid mycelial fragment. Such homogenate represents the dilution of $10^{-1}$. The homogenated sample was mixed by shaking and 10 $\mathrm{ml}$ of the original dilutions was transferred into sterile flask containing 90 of sterile saline solution and mixed carefully by shaking. Several dilutions were done in a sequential manner by tenfold serial dilution to obtain suitable number of colonies which could be easily counted.

Three types of media were used for the isolation and enumeration of fungi: dicloran rose-bengal chloramphenical agar medium (King et al., 1979), malt extract medium $+10 \% \mathrm{NaC} 1$ and malt extract medium $+20 \% \mathrm{NaC} 1$ (Blakeslee, 1915). The inoculated media were incubated at $25^{\circ} \mathrm{C}$ for $5-20$ days during which the developing colonies were counted, identified and the total mould count/ $\mathrm{g}$ were calculated. The identification of mould genera and species were carried out on the basis of their macroscopic and microscopic characteristics following the identification keys of Raper and Fennell (1965); Ellis (1971); Mossel (1977); Schipper (1978); Pitt (1979); Moubasher (1993); Samson et al. (2004); Leslie and Summerell (2006); Pitt and Hocking (2009).

\section{RESULTS}

Table 1: Sensory evaluation of the examined retailed salted Hydrocynus forskalii fish samples.

\begin{tabular}{ccc}
\hline & \multicolumn{2}{c}{ Salted fish samples } \\
\cline { 2 - 3 } General acceptability & No. +ve / 25 & $\%$ \\
\hline Excellent & 0 & 0 \\
\hline Good & 9 & 36 \\
\hline Medium & 13 & 52 \\
\hline Bad & 3 & 12 \\
\hline
\end{tabular}


Assiut Vet. Med. J. Vol. 61 No. 146 July 2015

Table 2: Minimum, maximum and mean $\pm \mathrm{SE}$ of $\mathrm{pH}$ values and frequency distribution of the examined retailed salted fish samples*.

\begin{tabular}{|c|c|c|c|c|c|}
\hline & & \multicolumn{4}{|c|}{ Salted fish samples } \\
\hline \multicolumn{2}{|r|}{ pH } & \multicolumn{2}{|c|}{ Skin } & \multicolumn{2}{|c|}{ Muscles } \\
\hline & & No. / 25 & $\%$ & No. / 25 & $\%$ \\
\hline \multirow{4}{*}{ 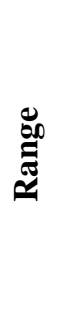 } & $>5.5-6$ & 0 & 0 & 1 & 4 \\
\hline & $>6-6.5$ & 1 & 4 & 4 & 16 \\
\hline & $>6.5-7$ & 11 & 44 & 12 & 48 \\
\hline & $>7$ & 13 & 52 & 8 & 32 \\
\hline \multicolumn{2}{|r|}{ Min. } & \multicolumn{2}{|c|}{6.50} & \multicolumn{2}{|c|}{5.99} \\
\hline \multicolumn{2}{|r|}{ Max. } & \multicolumn{2}{|c|}{7.52} & \multicolumn{2}{|c|}{7.32} \\
\hline \multicolumn{2}{|r|}{ Mean \pm SE } & \multicolumn{2}{|c|}{$7.04 \pm 0.27$} & \multicolumn{2}{|c|}{$6.81 \pm 0.35$} \\
\hline
\end{tabular}

* Egyptian standard (EOSQC, 2005): pH 6-6.5

Table 3: Minimum, maximum and mean $\pm \mathrm{SE}$ of $\mathrm{NaCl}$ percentage and frequency distribution of the examined retailed salted fish samples*.

\begin{tabular}{|c|c|c|c|}
\hline & & \multicolumn{2}{|c|}{ Salted fish samples } \\
\hline \multicolumn{2}{|c|}{$\mathrm{NaCl}$} & No. / 25 & $\%$ \\
\hline \multirow{4}{*}{$\begin{array}{c}\mathscr{E} \\
\mathbb{E} \\
\mathbb{E} \\
\mathbb{*}\end{array}$} & $>6-9$ & 0 & 0 \\
\hline & $>9-12$ & 2 & 8 \\
\hline & $>12-15$ & 8 & 32 \\
\hline & $>15-18$ & 15 & 60 \\
\hline \multicolumn{2}{|c|}{ Min. } & \multicolumn{2}{|c|}{10.23} \\
\hline \multicolumn{2}{|c|}{ Max. } & \multicolumn{2}{|c|}{17.55} \\
\hline \multicolumn{2}{|c|}{ Mean \pm SE } & \multicolumn{2}{|c|}{$15.03 \pm 1.77$} \\
\hline
\end{tabular}

* Egyptian standard (EOSQC, 2005): $\mathrm{NaCl} \%$ not less than $6 \%$. 


\section{Assiut Vet. Med. J. Vol. 61 No. 146 July 2015}

Table 4: Mean counts of fungal genera and species recovered from skin and muscle samples of retailed salted fish on DRBC, $10 \%$ $\mathrm{NaCl}$ malt extract agar and $20 \% \mathrm{NaCl}$ malt extract agar at $25^{\circ} \mathrm{C}$. The results are calculated as colony forming units (CFUs/g) in all samples*.

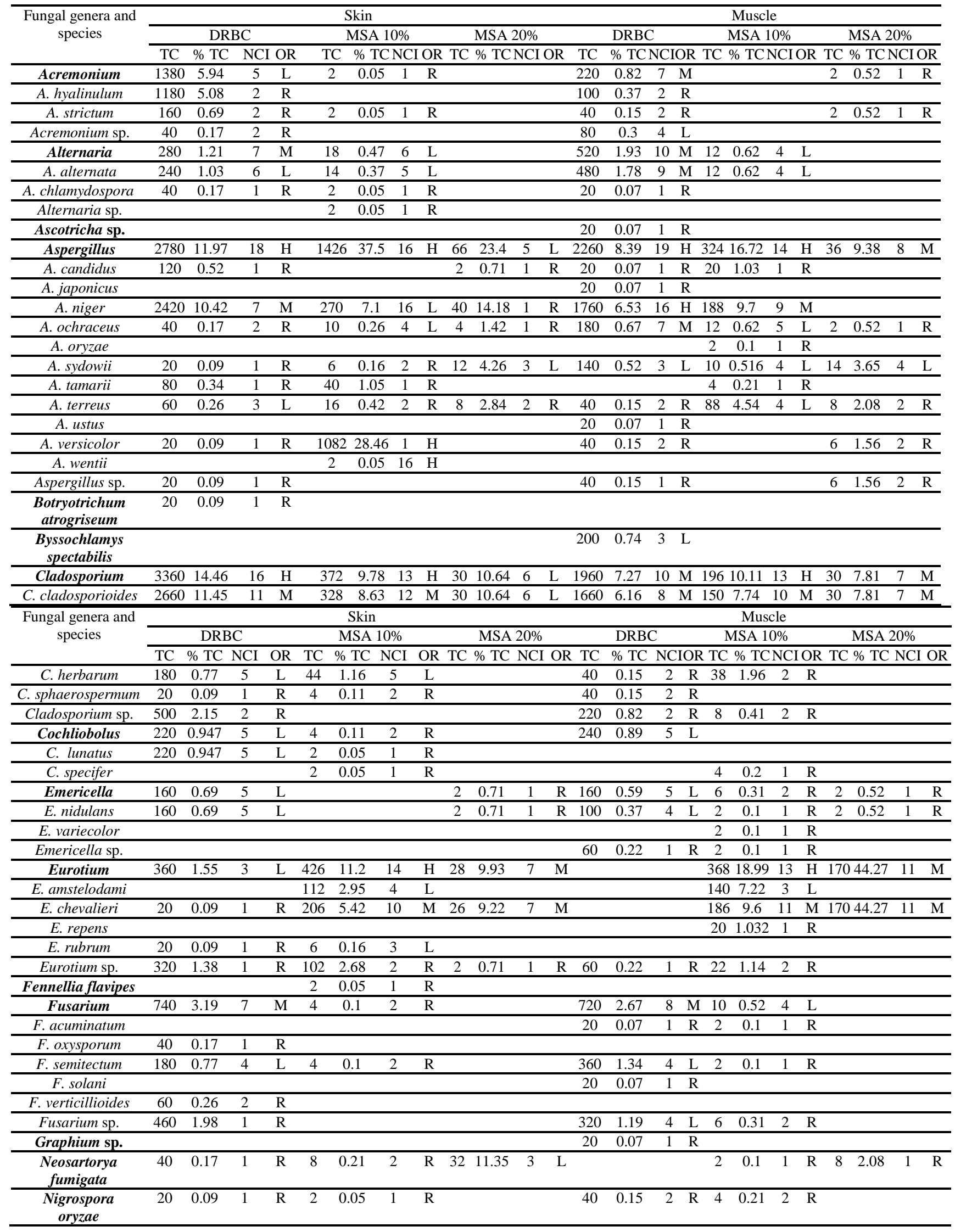


$\underline{\text { Assiut Vet. Med. J. Vol. } 61 \text { No. } 146 \text { July } 2015}$

Table 4: continued

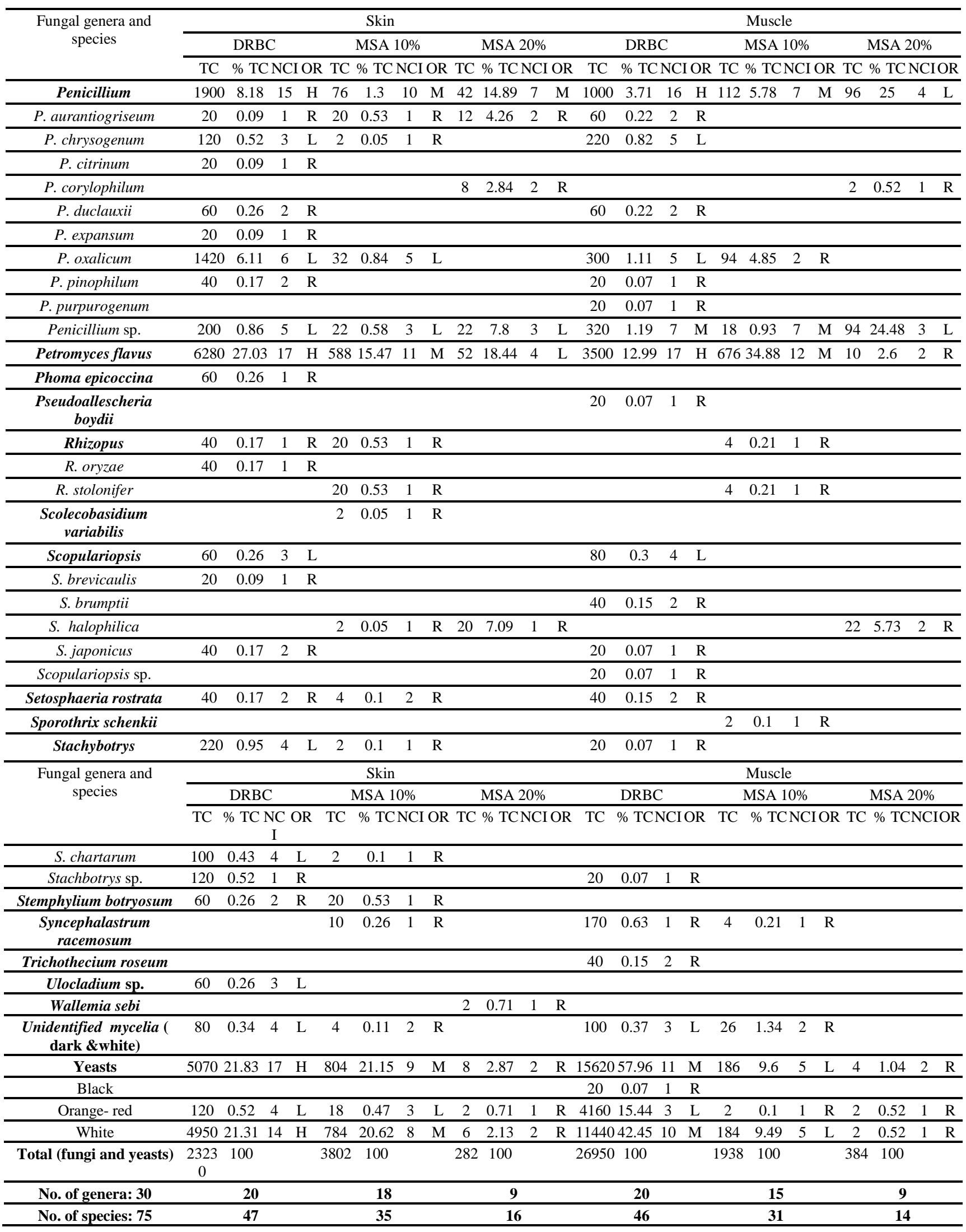

*TC: Total counts, \%TC: Percentage total count (calculated per total counts of all fungi), NCI: number of cases of isolation, OR:

Occurrence remarks; $\mathbf{H}=$ high (13-25), $\mathbf{M}=$ moderate (7-12), $\mathbf{L}=$ low (3-6), $\mathbf{R}=$ rare (1-2). 


\section{DISCUSSION}

The results of sensory evaluation (Table 1) indicated that most salted fish samples (88\%) were organoleptically accepted where $9(36 \%)$ and 13 (52\%) out of 25 samples were categorized as of good and medium quality, respectively. Only 3 (12\%) samples were of bad quality. Our results are nearly similar to those obtained by Ahmed (1976), Essa (1998) and Sayed (2008) who revealed that most salted fish samples they examined were physically normal. On the other hand different results were obtained by El-Morshdy et al. (1981) and Nayel (2007) who detected higher percentages of bad quality salted fish.

It is evident from the results recorded in Table (2) that the $\mathrm{pH}$ values of the samples varied from 6.5 to 7.52 with a mean value of $7.04 \pm 0.27$ on skin part of fish, whereas, on muscle part they varied from 5.99 to 7.32 with a mean value of $6.81 \pm 0.35$. Out of 25 samples of skin part of fish 11 and 13 were in the $\mathrm{pH}$ range of $>6.5-7.0$ and $>7$, respectively. Only one sample achieved $\mathrm{pH}$ value of 6.5. On muscular part of fish 4, 12 and 8 of the examined samples were in the $\mathrm{pH}$ range of $>6-6.5,>6.5-7.0$ and $>7$, respectively. However, only one sample achieved more acidic $\mathrm{pH}$ value of 5.99 .

From the summarized results in Table (2) it can be concluded that $96 \%$, and $80 \%$ of the examined samples of skin and muscular parts had $\mathrm{pH}$ values exceeded those of the Egyptian standards for salted fish (pH 6.0- 6.5) (EOSQC, 2005), only 4\% and $20 \%$ of samples, respectively, had values complying with the Egyptian standards. The $\mathrm{pH}$ values of the analyzed samples slightly differed from those previously obtained by Ahmed (1976), Abd ElRahman et al. (1988) and EI-Sheshnagui (2006). However, they were generally higher than those reported by NRCT (1981-1982), Sakai et al. (1983), Chang et al. (1991), Yatsunami and Echigo (1991), Silla-Santos (1996), Hernandez-Herrero et al. (1999a,b), Majumdar et al. (2006), Yung-Hsiang et al. (2006), Sayed (2008) for a variety of salted fish products. On the other hand, the obtained values were lower than those recorded by Steinkraus (1983), Surono and Hosono (1994) and Anihouvi et al. (2006).

For sodium chloride contents, the percentages were varied from 10.23 - $17.55 \%$ with a mean value of $15.03 \pm 1.77$. Out of the 25 examined salted fish samples 2, 8 and 15 had $\mathrm{NaCl}$ in the range of $>9$ $12 \%,>12-15 \%$ and $>15-18 \%$, respectively (Table 3 ). From these results, it is evident that all examined samples had $\mathrm{NaCl}$ content more than $6 \%$ which comply with the established Egyptian standards (EOSQC, 2005) for salted fish. Our results were nearly similar to those recorded by NRCT (1981-
1982) for pla-ra, Abd El-Rahman et al. (1988) for meloha, and Majumdar et al. (2006) for lona ilish. On the other hand they were slightly different from those registered by Shahine (1956), Ahmed (1976), Jennie and Muchtadi (1978), El-Morshdy et al. (1981), Chang et al. (1991), Surono and Hosono (1994), Essa (1998) and Sayed (2008). Lower values were reported by Sakai et al. (1983), Anihouvi et al. (2006) and ElSheshnagui (2006), while Steinkraus (1983), Sanni et al. (2002) and Yung-Hsiang et al. (2006) detected higher percentage.

It was observed that the fungal propagules recovered on DRBC were higher than those recovered on malt extract agar amended with either $10 \%$ or $20 \% \mathrm{NaCl}$ with the lowest count being recorded on $20 \% \mathrm{NaCl}$ malt extract agar (Table 4). This may be attributed to the effect of high concentration of salt which inhibits the growth of many species of fungi as reported by Atapattu and Samarajeewa (1990), Ismail et al. (1994), Essa (1998) and Ahmed et al. (2005). Addition of sodium chloride at high rate to the medium gives the opportunity to halophilic moulds (which probably found in salted fish samples) to appear in such media. The low mould counts recorded on $20 \% \mathrm{NaC} 1$ malt extract agar is in agreement with those obtained by Abdel-Rahman et al. (1988). However, higher mould counts were recorded by Ismail et al. (1994). This variation in mould counts in salted fish samples may be due to different levels of sanitary measures adopted during handling, manufacturing and storage.

It is noteworthy that many fungi were isolated on the three media and these were Acremonium strictum, Aspergillus niger, A. ochraceus, A. sydowii, A. terreus, A. versicolor, Cladosporium cladosporioides, Emericella nidulans, Eurotium chevalieri, Eurotium sp., Neosartorya fumigata, Penicillium chrysogenum, Petromyces flavus, Scopulariopsis sp. and orange-red and white yeasts.

On the other hand, some were recorded only on one medium such as Acremonium hyalinulum, Acremonium sp., Ascotricha sp., Aspergillus japanicus, A. ustus, Botryotrichum atrogriseum, Byssochlamys spectabilis, Setosphaeria rostrata, Fusarium oxysporum, F. solani, F. verticillioides, Graphium sp., Penicillium citrinum, P. duclauxii, $P$. expansum, P. pinophilum, P. purpurogenum, Phoma epicoccina, Pseudoallescheria boydii, Rhizopus oryzae, Scopulariopsis brevicaulis, S. brumptii, $S$. japonicum, Setosphaeria rostrata, Stachybotrys chartarum, Trichothecium roseum Ulocladium sp. and black yeasts on only DRBC; Alternaria sp., Aspergillus oryzae, A. wentii, Cochliobolus specifer, Emericella variecolor, Eurotium repens, Fennellia flavipes, Rhizopus stolonifer, Scolecobasidium variabile, and Sporothrix schenkii on $10 \% \mathrm{NaCl}$ MSA medium only; and Penicillium corylophilium 
and Wallemia sebi on $20 \% \mathrm{NaCl}$ MSA medium only (Table 4). Many of these fungi were isolated from salted fish in Egypt as reported by (Abdel-Rahman et al., 1988, Ismail et al., 1994, Essa 1998, Youssef et al., 2003 and Ahmed et al., 2005). Also, in other countries such as Sri Lank (Atapattu and Samarajeewa 1990 and Wheeler and Hocking 1993), Japan (Hitokoto et al., 1976), Indonesia (Wheeler et al., 1986) and in Ghana (Lu et al., 1988).

It is noteworthy also that many fungi were isolated from only skin parts and these were Alternaria sp., Botryotrichum atrogriseum, Fusarium oxysporum, F. verticillioides, Penicillium citrinum, $P$. expansum, Phoma epicoccina, Rhizopus oryzae, Scolecobasidium variabile, Scopulariopsis brevicaulis, Setosphaeria rostrata, Stachybotrys chartarum, Stemphylium botryosum, Ulocladium sp. and Wallemia sebi. On the other hand, others were isolated only from muscular parts such as Ascotricha sp., Byssochlamys spectabilis, Emericella sp., Fusarium acuminatum, F. solani, Graphium sp., Penicillium purpurogenum, Pseudoallescheria boydii, Scopulariopsis brumptii, Scopulariopsis sp., Sporothrix schenkii, Trichothecium roseum, and black yeasts.

It was observed that Eurotium was isolated in high frequency from 14 skin and 13 muscular samples out of 25 samples examined on $10 \% \mathrm{NaCl}$ malt extract agar as this genus is considered as halophilic fungus. Eurotium amounted $11.2 \%$ and $18.99 \%$ of the total fungal propagules on skin and muscular parts, respectively. E. chevalieri and E. amstelodami were the most prevalent species.

Cladosporium was frequently isolated on DRBC from 16 samples yielding $14.46 \%$ of the total propagules on skin part and from 10 samples yielding $7.72 \%$ of the propagules on muscular part. While on $10 \% \mathrm{NaCl}$ malt agar this genus was recovered in high frequency from 13 samples from both skin and muscular parts, accounting for $9.78 \%$ and $10.11 \%$ of the total propagules, respectively. C. cladosporioides and $C$. herbarum were the most prevalent species.

Both Aspergillus and Penicillium species were recovered in relatively high counts on dicloran rosebengal agar, in percentages of $11.97 \%$ and $8.18 \%$ of skin and $8.39 \% \& 3.71 \%$ of muscular parts of the total propagules, respectively. Both species were isolated on $10 \%$ salt malt extract agar, in percentages of $37.5 \%$ and 1.3 of skin and $16.72 \%$ and $5.78 \%$ of muscular parts of the total propagules, respectively. On $20 \%$ salt malt extract media they were recovered in percentages of $23.40 \%$ and $14.89 \%$ of skin and $9.38 \%$ and $25 \%$ of muscular parts of the total propagules, respectively. The total counts of genus Aspergillus and Penicillium were sharply decreased on $20 \% \mathrm{NaC} 1$ malt extract medium as affected by the presence of sodium chloride (Table 4). In Egypt, Youssef et al. (2003) isolated both Aspergillus and Penicillium species in percentages of $72.9 \%, 3.8 \%$, respectively; Essa (1998) isolated both Aspergillus and Penicillium species in percentage of $93.46 \%$ and $0.42 \%$ of the total propagules, respectively. Aspergillus (53.3\%) and Penicillium (44.4\%) species were also isolated by Ismail et al. (1994) from salted fish samples. Also, Abdel-Rahman et al. (1988) could isolate both Aspergillus and Penicillium species which accounted for $26.3 \%$ and $38.5 \%$ of the total propagules from salted fish samples, respectively. Several authors such as Watson (1993), McMahon (1994) and Hassan (1995) reported the importance of Aspergillus and Penicillium species in production of mycotoxins which have toxic and carcinogenic effects on public health.

Petromyces flavus (the aflatoxigenic Aspergillus species) followed by yeasts, Aspergillus, Cladosporium, Penicillium and Fusarium predominated on skin parts, while on muscular parts yeasts predominated over Petromyces flavus, Aspergillus, Cladosporium, Penicillium, Fusarium in the number of propagules.

From the current results, it could conclude that some of the examined salted fish are highly contaminated with moulds due to neglected sanitary measures. Furthermore, mishandling of such types of fish resulted in presence of a variety of fungi in high counts.

The incidence of moulds could be attributed to improper sanitation during catching, handling, processing, salting storage, transportation, distribution and marketing of fish (Novotny et al., 2004). Contaminations with a variety of mould species resulted in undesirable changes of fish and rendering it unfit for marketing and increase the risk of infection with respective disease to consumers as a probable result of aflatoxins production by some fungal strains (Ward and Baaj, 1988; Dimond and Kendall, 2011).

\section{REFERENCES}

Abd El-Rahman, H.; El-Khateib, T. and Refai, R.S. (1988): Microbiological studies on the Egyptian salted fish "Moloha". Assiut Vet. Med. J., 19 (38): 90-97.

Adams, M.R.; Cooke, R.D. and Rattagool, Pongpen (1985): Fermented fish products of South East Asia. Trop. Sci., 25: 61-73.

Ahmed, A.M.; Ismail, S.A. and Abd-El-Rahman, H.A. (2005): Quantitative, qualitative and toxigenic evaluations of xerophilic mould in traditional Egyptian salted fish (Molouha). J. of food safety, 25, 9: 18.

Ahmed, H.Y. (1976): Studies on the sanitary 
improvements of locally manufactured salted Fish. Ph. D. Thesis (Meat Hygiene), Fac. of Vet. Medicine, Assiut University.

AOAC "Association of Official Analytical Chemists" (1980): official methods of analysis of the Association of Official Analytical Chemists. $13^{\text {th }}$ Ed. Horwitz, W. (edit.). Washington D.C., AOAC.

AOAC (1995): Official Methods of Analysis of AOAC International. $16^{\text {th }}$ Ed., Volume II: Food Composition; Additives; Natural Contaminants. Cunniff, Patricia. (edit.) AOAC International, Virginia, USA.

APHA (American Public Health Association) (1985): Compendium of methods for the microbiological examination of foods. The American Public Health Association, Speck, M.L., (ed.) $2^{\text {nd }}$ Ed Washington, D.C.

Anihouvi, V.B.; Ayernor, G.S.; Hounhouigan, J.D. and Sakyi-Dawso, E. (2006): Quality characteristics of lanhouin, a traditionally processed fermented fish product in the Republic of Benin. African Journal of Food Agriculture Nutrition and Development, 6 (1): 1 - 15. Online: www.ajfand.net

Atapattu, R. and Samarajeewa, U. (1990): Fungi associated with dried fish in Srilanka. Mycopathologia, 111, 1: 55- 59.

Balachandran, K.K.; Perigreen, P.A. and Nair, M.R. (1978): Fish consumption trends in India. Proc. IPFC, 18 (3): 435-438. (Cited after, FAO, 1981b).

Blakeslee, A.F. (1915): Lindner's roll tube method of separation cultures. Phyto pathol., 5: 68-69.

Chang, C.; Ohshima, T. and Koizumi, C. (1991): Lipid, free amino acid, and organic acid compositions of rice-bran-fermented sardine. Nippon Suisan Gakkaishi, 57(8): 1579-1585.

Dimond, N. and Kendall, P. (2011): Food Storage for Safety and Quality. Colorado State University no. 9. 310 .

Dorner, W.J. (1983): Production of mycotoxin by Aspergillus tamarii Kita. Appl. and Enviro. Microbiol., 46, 6: 1435-1439.

Egyptian Organization for Standardization and Quality Control "EOSQC" (2005): ESS 1725, part 3 for salted fish (Moluha).

Ellis, M.B. (1971): Dematiaceous hyphomycetes. Commonwealth agricultural Bureaux.

El-Morshdy, A.; Zeidan, M.A. and Sedik, M.F.S. (1981): Studies on physical, chemical and bacteriological status of salted fishes in Sharkia province. Assiut Vet. Med. J., 8 (15\& 16): 127-134.

El-Sebaiy, Laila, A. and Metwalli, S.M. (1989): Changes in some chemical characteristics and lipid composition of salted fermented Bouri fish muscle (Mugil cephalus). Food Chemistry, 31: 41-50.

El-Sheshnagui, Sawsan, M.L. (2006): Sanitary evaluation of some salted fishes in Alexandria. Assiut Vet. Med. J., 52 (110): 96-110.

Essa, H.H.Y. (1998): Mycological Status of Moloha, Smoked Herring and Frozen Mackerel fish in Assiut Province. Ph.D. Thesis (Meat Hygiene), Fac. Vet. Med., Assiut University.

FAO (1981a): The Prevention of Losses in Cured Fish. FAO Fisheries Technical Paper No. 219.

FAO (1981b): Guidelines for chilled fish storage Experiments. FAO Fisheries Technical Paper No. 210.

FAO (1994): Assurance of Seafood Quality. Huss, H. H. (edit.), FAO Fisheries Technical Paper No. 334.

Govindan, T.K. (1985): Fish Processing Technology. Oxford and IBH Publishing Co., New Delhi. p. 252. (Cited after, Tamil et al., 1999).

Hassan, G. (1995): Aspergillus flavus and Aspergillus parasiticus, aflatoxigenic fungi of concern in food and feeds. J. Food Prot. 58, 12: 1395.-1404.

Hernandez-Herrero, M.M.; Roig-Sagues, A.X.; Lopez-Sabater, E.I.; Rodriguez-Jerez, J.J. and Mora-Ventura, M.T. (1999a): Protein hydrolysis and proteinase activity during the ripening of salted anchovy (Engraulis encrasicholus L.). A microassay method for determining the protein hydrolysis. J. Agric. Food Chem., 47: 3319 - 3324.

Hernandez-Herrero, M.M.; Roig-Sagues, A.X.; Lopez-Sabater, E.I.; Rodriguez-Jerez, J.J. and Mora-Ventura, M.T. (1999b): Total volatile basic nitrogen and other physicochemical and microbiological characteristics as related to ripening of salted anchovies. J. Food Science, 64 (2): 344 - 347.

Hitokoto, H.; moozumi, S.; Wauke, T.; Sakai S.; ZenYoji, H. and Benoki, M. (1976): Annual Rep. Tokyo Metrop. Res. Lab. Public H1Th 27, 36.

Ikeme, A.I. (1986): Extending the shelf-life of smoked mackerel. FAO Fisheries Report, Suppl., 329: 144-149.

Ismail, M.A.; Nassar, A.; Ahmed, A. and Youssef, $H$. (1994): Mycological status of ready to eat salted fish. Assiut Vet. Med. J., 32, 63: 74-81.

Jennie, B.S.L. and Muchtadi, D. (1978): Agriculture Product Microbiology, p. 92 - 93. Department of Education and Culture, Jakarta, Indonesia. (Cited after, Surono and Hosono, 1994)

Karnop, G. (1980): Effect of storage temperature on the keeping quality of smoked habilut. Flischwirtschaff. 37, 3: 125- 128.

King, A.D.; Hocking, A.D. and Pitt, J.I. (1979): Dichloran rosebengal medium for enumeration and isolation of moulds from foods. Appl. Environ. Microbiol., 37: 959-964.

Leslie J.F. and Summerell B.A. (2006): The Fusarium Laboratory Manual. Blackwell Publishing Ltd, Iowa.

Lu, J.Y.; Pace, R.D. and Plahar, W.D. (1988): Survey 
of the microbial quality of dry fish, Casava and Okra in Ghana. J. Food Prot., 51, 8, 660-662.

Lyhs, U.; Hatakka, M.; Maki-Petays, N.; Hyytia, E. and Korkeala, H. (1998): Microbiological quality of Finnish vacuum-packaged fishery products at retail level. Archiv fur Lebensmittelhygiene, 49 (6): 146-150.

Majumdar, R.K.; Basu, S. and Nayak, B.B. (2006): Studies on the biochemical changes during fermentation of salt-fermented Indian shad (Tenualosa ilisha). Journal of Aquatic Food Product Technology, 15 (1): 53 - 69.

McMahon, G. (1994): The genetics of human cancer, implications for ecotoxicology. Environmental health perspective Dec. 102 suppl. 12: 75-80.

Mossel, A.A.D. (1977): Microbiology of Foods. Univ. of Utricht. Fac. of Vet. Med. The Netherland.

Moubasher, A.H. (1993): Soil fungi in Qatar and other Arab countries. The center for scientific and Applied Research.

National Research Council of Thailand "NRCT" (1981-1982): Report on Thai Traditional Fermented Food Research Project, Phase 1, p.51 (Cited after, Adams et al., 1985)

Nayel, M.S.Kh. (2007): Microbiological Status of Some Marketed Canned and Pickled Fish. M.V.Sc. Thesis (Food Control) Fac. Vet. Med., Moshtohor, Benha University.

Novotny, L.; Dorska, L.; Lorencova, A.; Beran, V. and Pavlik, I. (2004): Fish: a potential source of bacterial pathogens for human beings. Review Article. Vet. Med.-Czech, 49 (9): 343-358.

Perisse, J.; Stoces, F. and Paci, C. (1974): Zambia, The food economy of Zambia. Rome, FAO, ENS: DP / ZAM / 69 /512 Technical Report 1. (Cited after, FAO, 1981b).

Pitt, J.I. (2000): Toxigenic fungi and mycotoxin. British Medical Bulletin, 56 (1): 184-192.

Pitt, J.I. (1979): An appraisal of identification methods for Penicillium species, novel taxonomic criteria based on temperature and water relations. Mycologia, 65: 1135-1157.

Pitt, J.I. and Hocking, A.D. (2009): Fungi and food spoilage Book, $3^{\text {rd }}$ Ed., Springer, New York.

Raper, K.B. and Fennell, D.L. (1965): The genus Aspergillus. Williams and Wilkins company, Baltimor.

Sakai, H.; Caldo, G.A. and Kozaki, M. (1983): The fermented fish food Burong- isda in the Philippines. J. Agriculture Science (Tokyo), 28(2): 138 - 144. (Cited after, Adams et al. 1985).

Samson, R.A.; Hoekstra, E.S. and Frisvad, J.C. (2004): Introduction to food borne fungi, $7^{\text {th }}$ Ed. Centraal bureau voor Schimmelcultures, Utrecht.

Sanni, A.I.; Asiedu, M. and Ayernor, G.S. (2002):
Microflora and chemical composition of monomi, a Ghanaian fermented fish condiment. J. Food Comp. Analy., 15: 577-583.

Sayed, S.M. (2008): Egyptian traditional salted fishes: processing technology and quality control monitoring. Ph.D. Thesis Fac. of Vet. Medicine, Assiut University.

Schipper, M.A.A. (1978): A studies on certain spp. of Mucor with a key to all accepted spp. studies on Mycology. Baam, 17: 1-52.

Shahine, A.B. (1956): Chemical Composition of Salted Fermented Fish "Feseekh" at Various Stages of Fermentation. M.Sc. Thesis, Cairo University. (Cited after El-Sebaiy and Metwalli, 1989).

Silla Santos, M.H. (1996): Biogenic amines: their importance in foods. Int. J. Food Microbiol., 29: 213-231.

Steinkraus, K.H. (1983): Handbook of Indigenous Fermented Foods. Marcel Dekker, Inc., New York. p. 494 - 498. (Cited after, Surono and Hosono, 1994).

Surono, U.S. and Hosono, A. (1994): Chemical and aerobic bacterial composition of "Terasi", a traditional fermented product from Indonesia. J. Food Hyg. Soc. Japan, 35 (3): 299-304.

Tamil, Selvi, A.; Jeyachandran, P.; Indra, Jasmine, G.; Shanmugam, S.A. and Kannappan, S. (1999): Keeping quality of salt cured shark (Carcharhinus sorrah). J. Food Sci. Technol., 36 (5): 469-471.

Ward, D.R. and Baaj, N.J. (1988): Factors affecting microbiological quality of seafoods. Food Technol., 42, 3: 85-89.

Watson, D.H. (1993): Safety of chemicals in food chemical contaninats. Ministry of Agriculture, Fisheries and Food, London, p. 85-93.

Wheeler, K.A.; Hocking, A.D.; Pitt, J.I. and Angawati, A.M. (1986): Fungi associated with Indonesian dried fish. Food. Microbiol. 3, 4, 351-357.

Wheeler, K.A. and Hocking, A.D. (1993): Interaction among xerophilic fungi associated with dried salted fish. J. Appl. Bacteriol. 74; 2: 164-169.

Yatsunami, K. and Echigo, T. (1991): Isolation of salt tolerant histamine-forming bacteria from commercial rice-bran pickles of sardine. Nippon Suisan Gakkaishi. 57 (9): 1723-1728.

Youssef, M.S.; Abo-Dahab; N.F. and Farghaly, R.M. (2003): Studies on mycological status of salted fish (Moloha) in Upper Egypt. South Valley Univ. J. Mycobiology, 31(36): 166-172.

Yung-Hsiang, T.; Chueh-Yueh, L.; Liang-Tan, C.; Tsong-Ming, L.; Cheng-I, W. and Deng-Fwu, $H$. (2006): Histamine contents of fermented fish products in Taiwan and isolation of histamine-forming bacteria. Food Chem., 98: 64-70. 


\section{تقييم الحالة الفطرية لأسماك كلب السمك المملح في محافظة أسيوط}

\section{هشام عبل المعز إسعاعيل ، ماضي أحمد إسعاعيل ، حسين بيوسف أحمد ، علاء اللبين كمال بيوسف}

Email: hesham.ismail@yahoo.com Assiut University web-site: $\underline{\text { www.aun.edu.eg }}$

أجريت هذه الدر اسة علي هب عينة من اسماك الملوحة (كلب السمك المملح) تم تجميعها عشو ائيا من منافذ بيع الأسماك المملحة في

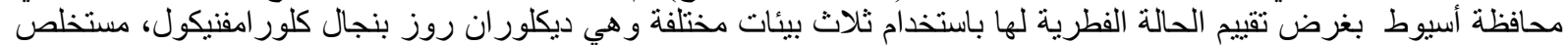

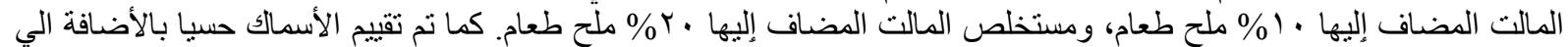

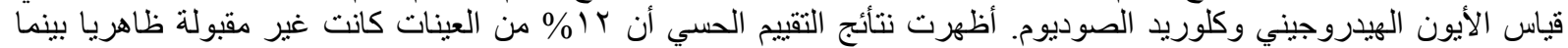

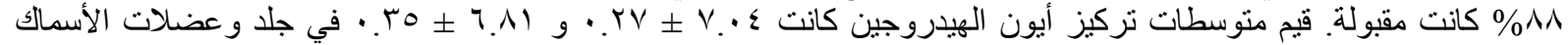

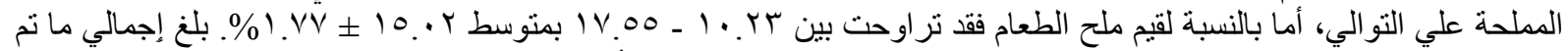

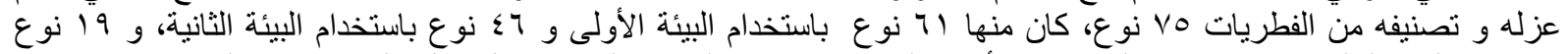

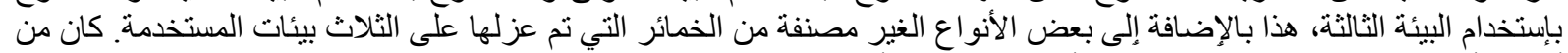

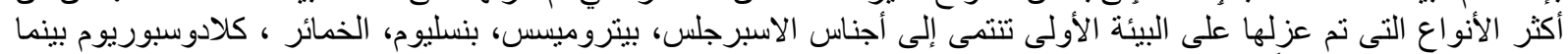

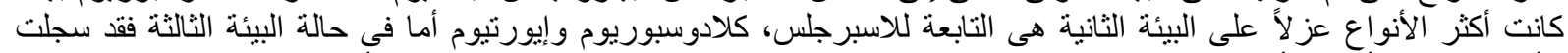

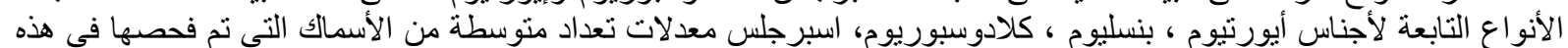

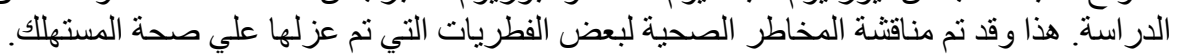
الكلمات الكاشفة: فطريات، تقييم حسي، كلوريد الصوديوم ، الأيون الهيدروجيني ، الأسماك المملة. 